\title{
Sustainability of spatial context of historical core areas in Indonesian cities
}

\author{
E. Ellisa \\ Department of Architecture, Faculty of Engineering, \\ University of Indonesia, Indonesia
}

\begin{abstract}
Colonization affected urban areas in Asian countries, where none had existed before because they were needed as administrative centres in the imperial system. As one of the great waves of globalisation, colonization covered the entire surface of Asian countries, including Indonesia. Colonial towns and cities left impressions and shaped succeeding built forms in the next period. Using some cases of former colonial cities in Indonesia and supported by a detailed study of Medan and Jakarta, this paper constructs the pattern of urban fabric through analysis of old city maps and images as well as observation of existing cities. The study reveals the typical morphology among those cities that demonstrates the linkages between colonial urban form and social, economic and symbolic dimensions during the colonial era. Beyond these urban development forces, much effort therefore should be applied to sustain the intrinsic sense of colonial urban context that is identified as the local language of the Indonesian urban form.
\end{abstract}

Keywords: urban structure, transformation, sustainability, colonial urban context, design guideline, living function.

\section{Introduction}

The term Indonesia refers to the sovereign territory of Republic Indonesia, one of the world's most extensive archipelago, which contains 13,677 islands, of which 6,000 are inhabited. Among the islands, Java Island is the political, geographic and economic centre of the country. Before the colonization period, the country generally did not have a strong urban tradition. Many scholarly overviews of the early Indonesian urbanization during pre-colonialism consisted of numerous 
coastal settlements in Java Island that were instrumental in the formation of overseas links such as Banten, Tuban, Demak, Gresik and several others. However, they were not always recognized as such compact western towns, although indeed they are called them as towns and not villages. Other scholars considered these early Indonesian towns merely aggregates of villages and they doubted their urban character. Nas mentions that the early Indonesian towns functioned as a centre of state; they were recognized as a focus and not limited to a single urban area, as was the case in medieval Europe [1].

Indonesian urbanism was succeeded by a period marked by the founding of cities created by European colonial powers. The colonialism in Indonesia was initiated by the Portuguese in the 16th century, followed by the Dutch at the turn of the 18th century, interrupted by the British between1811-1815 and continued by the Dutch until the middle of the 20th century. Under foreign dominance, urban growth accelerated after 1800, when European powers adopted a policy of territorial and political imperialism [2]. The period of colonial penetration and development between 1700 and 1900 constituted the main phase of urban development. Almost 200 urban places in Indonesia were founded after 1900 while other larger towns date back to earlier periods [3].

\section{General features of urban structures}

It is interesting to understand how a foreign power could establish a city with indigenous people. During the first two centuries the Dutch occupation, their influence on urban morphology and urban life were felt primarily in the new settlement of Batavia, which at first was built to resemble Amsterdam in various ways. It was built along the canals with a defensive wall representing the characteristics of fort town or "het Kasteel"(Fig.1). Later on, the Indonesian and

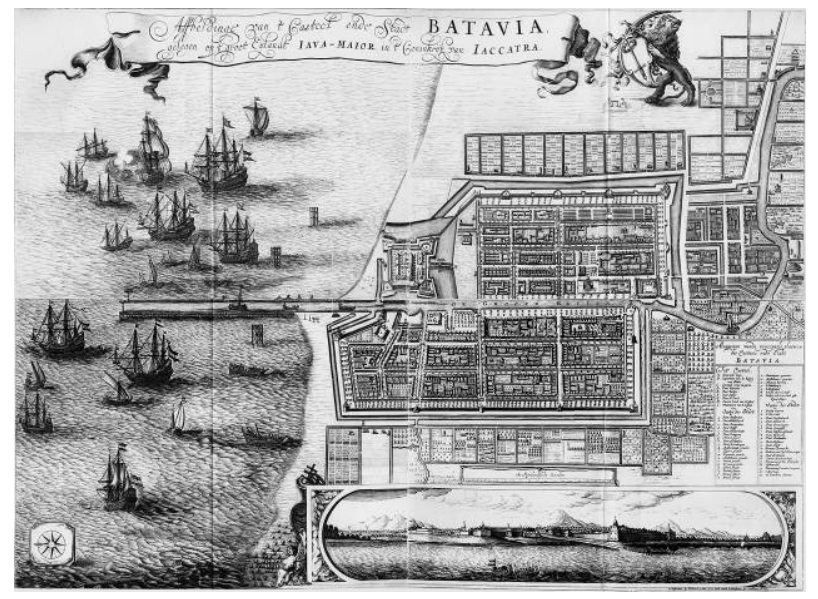

Figure 1: $\quad$ Map of Batavia drawn by Clement de Jonghe in around 1650. 
the Dutch cultures intermingled into Indische culture [4]. This culture implied a spacious life style and induces the images of Indish town, which applies to some regency capitals in Java.

After 1870 the liberalization of Indonesian society took place and the open door politics attracted many adventurous Dutch to try their fortune. This tendency emerged into another kind of new town formation that was marked by the search for an urban form fitting the European ways of life in the tropical setting of the Indonesian archipelago. The cultural hybrid of the Indish towns gradually was replaced by new colonial towns and was characterized by cultural segregation due to an influx of large numbers of newcomers to strengthen both the government bureaucracy and private enterprise, which sprung up in the 1870 s.

\section{Urban area composition during the colonial age}

In the 19th century the Dutch government's machinery and its activities in the Indonesian archipelago had expanded so greatly that it was impossible to supervise the administration over the whole archipelago from the central authority of governor general. This encouraged the Dutch to establish the system of municipalities after the model of those in the Netherlands called Stadsgementen, for the towns both inside and outside Java [5]. The first municipality was inaugurated in Batavia in 1905, followed by Surabaya, Semarang and Bandung in 1906. Urban areas were then placed directly under Dutch administration and Dutch law; accordingly foreign nationals were permitted to own land. The administrative centre was set up and a state apparatus with a police force and prison system was formed. The coastal territories in the archipelago that already had well established government structures and trade experienced only a few further fundamental changes. While in the inland areas, urban developments were more stimulated by the setting up of a European administration, the expansion of transport network and the realization of economic resources such as central collective points and the storage and the processing places of agricultural commodities.

\subsection{The town structure}

Dating back to the early Indian-Hindu influences, basically the layout of the early towns is typical [6]. They have a regular ground plan with the single point situated in the center of the town. In Java it was given the name alun-alun, otherwise padang in Sumatera meaning something like flat field. As we can observe about the Javanese old cities, alun-alun together with three other elements of palace, mosque and pasar (market) formed a pattern called catur tunggal (four in one) means four components in one area [7]. In Java the four city compartments in the catur tunggal pattern has given rise to be a symbol or center of urban territory. The spatial growth of the city had developed by supporting the role of catur tunggal elements. Kauman - a traditional urban settlement dominated by Islam followers grew up around the mosque. The 
market reinforced trading activities in the city and allowed people, mainly Chinese merchants, to come and to create Chinatowns or Pecinan. Areas around palace grew into a noble residential district or Dalem.

The arrival of the Dutch in the $16^{\text {th }}$ century led to an important change in most Indonesian colonial towns in Java. The Dutch contributed to an urban character by developing western facilities such as a fortress, post office, bank, church and a Dutch residential ward as part of the city's form or morphology. In the city center, to control the indigenous communities, the Dutch used the system of indirect rule, which was reflected in the morphology of the towns within the regions. Examples can be seen in Kabupatens or regency cities of Java. As has been described by Tilemma in his book entitled Kromoblanda, the center of a regency city was arranged in what Ronald Gill called the 'ceremonial urban pattern' to display the radiance of power by using alun-alun as the focus for arrangement of the city center [8]. An indigenous regent's residence or dalem was placed in the North facing the alun-alun in a stern axial relation with the paseban (guard shelter) and banyan trees. The residence of the Dutch assistantresident was placed in the North. The mosque was in the West. Although there was an exception that often the jail was placed on the East side of the mosque. Altogether, these elements were an expression of display of foreign authority, control of indigenous power, culture and religious beliefs. Along the ring of the buildings facing alun-alun were situated the school, the church, the hospital, the club house (Societit Concordia) and dwellings of important Dutch officials. The Chinese quarter where the commercial activities held was located close to the main road (Fig.2).

Basically, this pattern of town structure was applied in cities Java. In outer Java, it was modified in numerous different ways, depending on dominant functions, special cultural features and existing physical characteristics of the towns. An example is the city of Medan, located on Sumatra Island. The city was established during the end of the 19th century, and the development of the city reached the peak during the 1930s, at the time when the Dutch period nearly ended [9]. In Medan, the Dutch also located a square that took a single block in the city centre and acted as the key composition of the town structure. However, the buildings arranged around the square were dominated by the Dutch official and commercial buildings including town hall, post office, bank, hotel, clubhouse, office buildings and train station. Altogether, these formed the sense of a square as the civic symbol of the town (Figure 3 ).

While in Java the Dutch set the domestic ruler in the city centre, in Medan the Sultan's centre was totally separated and remote to the government town centre. In Java, the Dutch also used the ceremonial urban pattern constituting the traditional alun-alun in structuring the cities where both foreign and indigenous elements existed together mutually. In Medan, the Sultan was given autonomous administrative power, although it was only a symbolic power due to his dependence on the colonial government, that it enabled him to set his own state centre. 


\subsection{The block and building pattern}

Industrial capitalism brought by the Dutch transformed the informal arrangement of rural settlements into a formal urban plan. The cities were planned consciously and set down after the process of consolidation of a vast area of land. Road and street networks were developed, taking into full account modern town planning practices. The Dutch successfully demonstrated that their dominances enabled them to provide an inequitable distribution of resources, which including the urban space. The foreigners who were actually small in their population numbers dominated the urbanized areas. On the other hand, the natives who become the dominant population had to live in the periphery of the city [10]. In Batavia, racial distinctions also were the paramount basis for social ranking, and the allocation of occupational and many other kinds of opportunities in the cities.

What became clear is that almost all of the colonial cities displayed the block patterns that give a unique order and structure to each district (Figure 4). In the

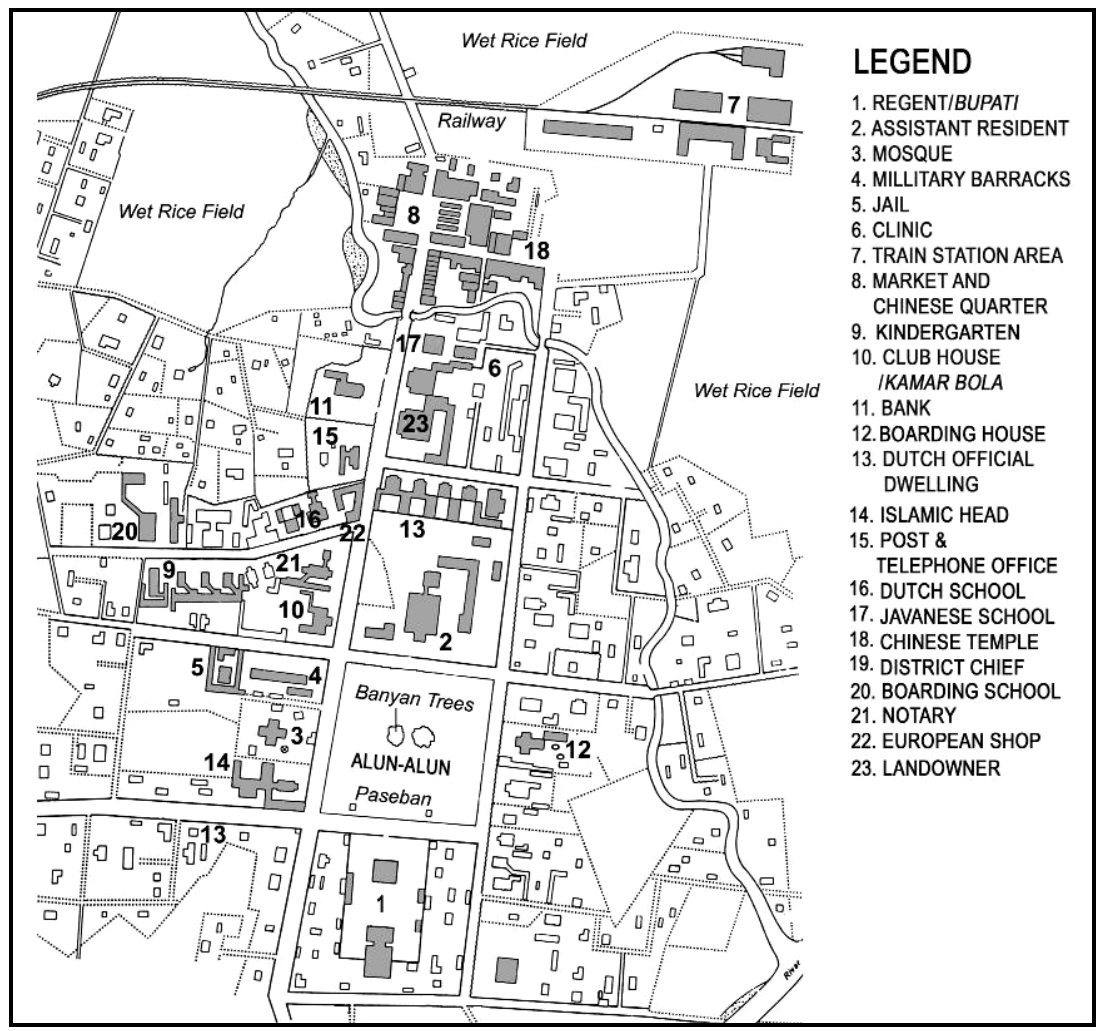

Figure 2: $\quad$ Pictorial map of Regency Capital on Java according to Tilemma Redrawn by the author from Rutz,1987. 


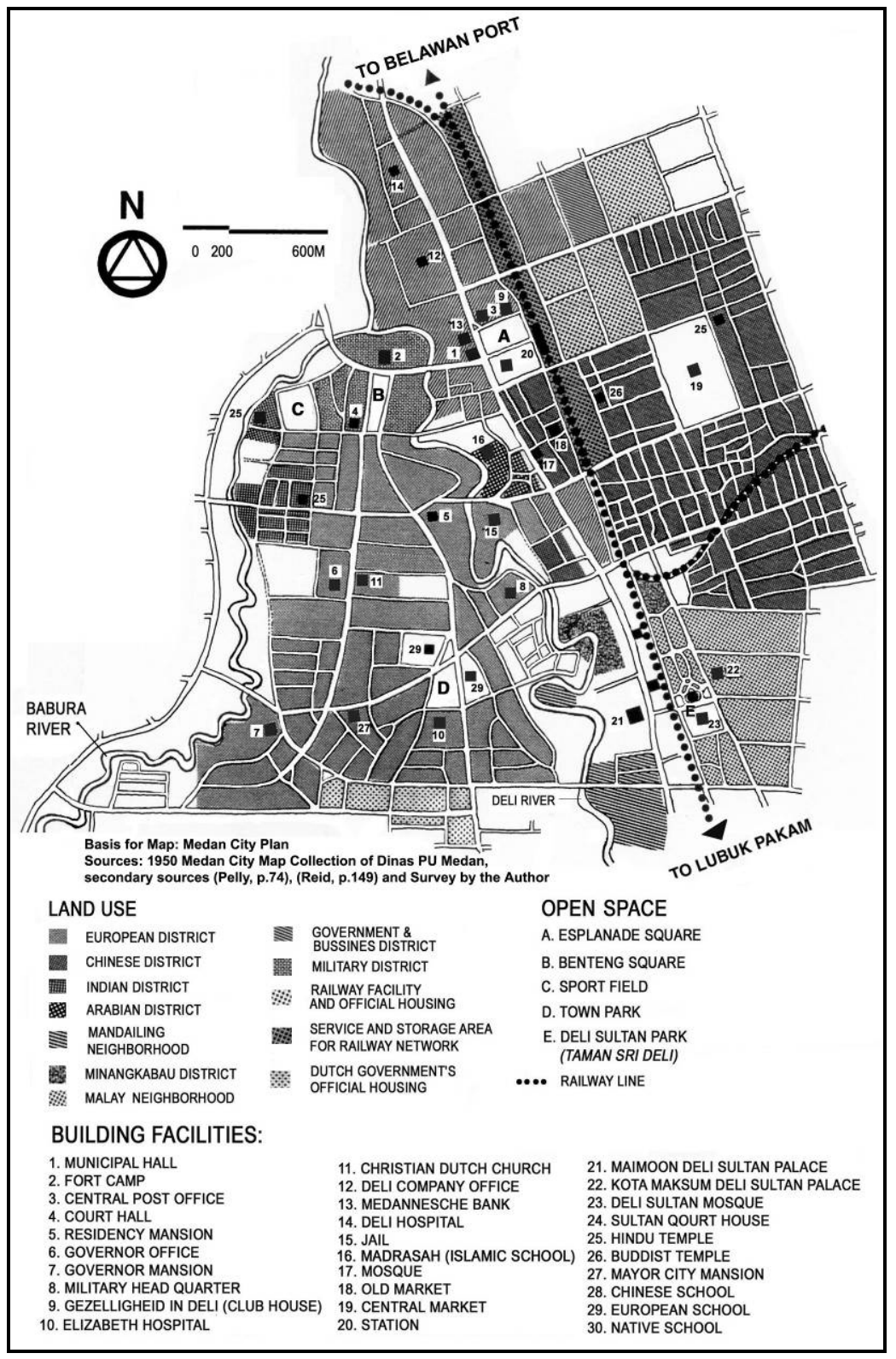

Figure 3: $\quad$ Town structure and land use of Medan during the 1950s.

European residential district the area was divided into various shapes of blocks by secondary streets and arranged based on the dimension of the site. A typical layout was a single loaded block with the front and rear facing the street or double loaded block consisting of two rows of single houses with the front facing 
the street and back to back to each other. The residential lots were spacious and green so as to provide enough opportunity to enjoy the tropical climate. The streets were broad and straight and sometimes moved in gentle curves with small green spaces, boulevards and fine border houses. The sizes of building lots were approximately between 600 to 2000 square meters. They were set up as single family dwellings or duplex houses and designed using modern suburban villa prototypes that had a lot in common with the Dutch villa. Building setbacks designed from the street to make a spacious tropical garden with sufficient trees. The building density was strictly controlled to be always considerably low. These were the ways that the Dutch tried to adapt their buildings to the tropical and hot climatic condition. Observers in the mid-19th century often admired the extended layout of the roads and dense construction of the houses that made 'you believe that you were in a European suburb'. This type of tropical garden city grew up first of all in Weltevreden in Batavia and then in Surabaya, Semarang and then spread to other towns and cities with European populations, such as Malang, Medan, Bogor, Makasar and others.

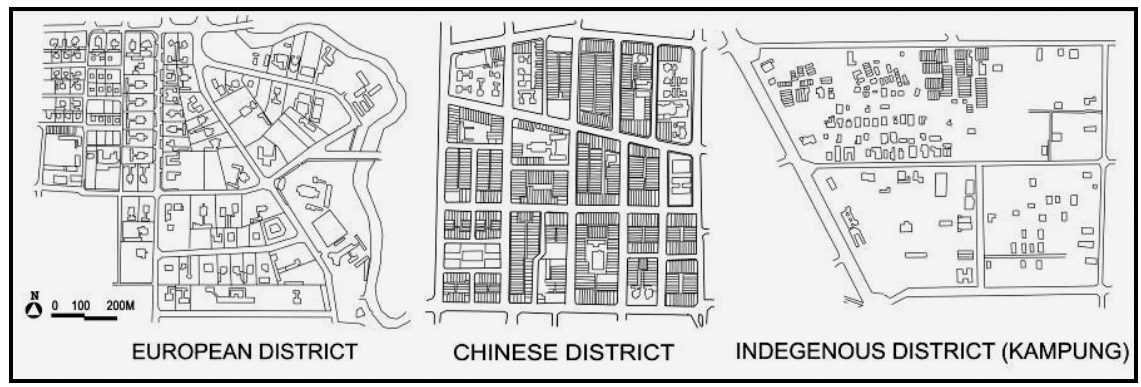

Figure 4: Comparison of block size and pattern in European, Chinese and indigenous district based on 1950 Medan City Map collection of department of public work.

In Chinese neighborhoods the area was divided into almost uniform blocks. These can be a long narrow block measuring 0.5-1 hectare in size accommodated within a tight series of deep parcels. The block consists of 30-50 units of building lots in which each lot faced a proper street, back to back to each other and divided by small alleys that were no more than footpaths. Another type can be a single-loaded block or rectangular block divided into small land parcels with the front and back facing the street. In contrast to the European district, almost all the grounds were covered by buildings, forming a high density of building blocks. The buildings were often two or three storeys, a small shop at ground level with a dwelling above, connected each other with a shared wall, occasionally even a roof.

The indigenous clusters in the kampung area were extensive; the layout of buildings was scattered and irregular so it was difficult to grasp the pattern. There was no exact boundary between the housing lots since there was no rule in the setting out of the houses. As the clusters absorb many incoming immigrants, 
the settlements were continuously developing with a high degree of intensification. Dutch reports often mentioned that numerous kampungs faced the problem of rapid deterioration of environmental quality. The close proximity of houses, built of easily inflammable materials, coupled with inadequate hygiene meant that the kampungs were frequently swept away by fire or epidemic disease.

\section{Urban transformation in the post-colonial age}

Today, less than 70 years after the end of the colonial age, the former colonial cities have became large cities of which 10 cities have populations of one million or more and 13 cities have populations between half to one million [11]. The largest city is Batavia that became Jakarta, the capital of Indonesia. Jakarta has developed into a metropolis of 9 million residents which increases to nearly 12 million during the working day. The city has undergone far-reaching changes since the urban scheme inherited from the Dutch was redesigned into a modern city planning master plan.

Shortly after independence in 1945, for the first time a concept plan for Greater Jakarta was set up by a committee of Indonesian and Dutch planners. The concept was consistent with the vision of a Sukarno president to transform the colonial capital into a symbol of national unity [12]. He distinctively imprinted the build and social environment of Jakarta as an exercise for raising national prestige to blot out the lingering images of the colonial past. Defining the former Konigsplein and Benteng Square as the cores, the city partitioned by a series of highways and encased within a greenbelt which defined the outer limit of urban development. The city center incorporated into a new satellite city through massive annexation of peripheral areas around Jakarta and created concentric layers. This thread of conceptual continuity extends from the 1950s all the way into the 1990s. In 1980, the development of the road networks intensively created suburbanization and forced the metropolis extended deep into the periphery. Yet the concept did not mesh at all with the historical pattern of development that the old buildings in the old city have clung on to exist.

Although antipathy toward structural symbols of the city's colonial past marked the early national period, later on the city leadership gained an appreciation of the value of linking the historic city to the modern metropolis. Around the 1970 s the period generated a series of gubernatorial regulations that broadened the scope of preservation activities by recognizing some old districts that would become the focus of preservation planning in the 1980s and 1990s. However, enforcement of regulations was more challenging than their promulgation, since for a long time, the colourful historical sites and relics of Jakarta still have been largely abandoned. Yet, the ineffectiveness of the grand revitalization schemes that attempted to use historic preservation for economic development in Jakarta should not be regarded as the final word on the impact of preservation efforts in the city, since areas such as Merdeka Square and the residential neighbourhood of Menteng retained their attraction as preservation areas. 
In 2006, the Old Town Revitalization Plan produced an approach to transforming the oldest core area of Kota into an attractive and accessible tourist area. The goal is to transform the old town into a cultural tourist spot that features heritage values but still allows room for economic activities. However, the area had changed very little from the architecturally distinctive but deteriorated, congested and economically marginal section of the city of Jakarta (Figure 5). There is no sign of any commercial investment related to attracting tourism. Without historical attractions on a scale comparable to other tourist destinations, such as Yogyakarta and Bali, the old city found difficulties to capture its share of the increase in tourism. While restoration of several landmark structures and upgrading occurred, the area also remained inaccessible to pedestrians because of intensive traffic and the deleterious effect of nearby industrial and warehouse activities.

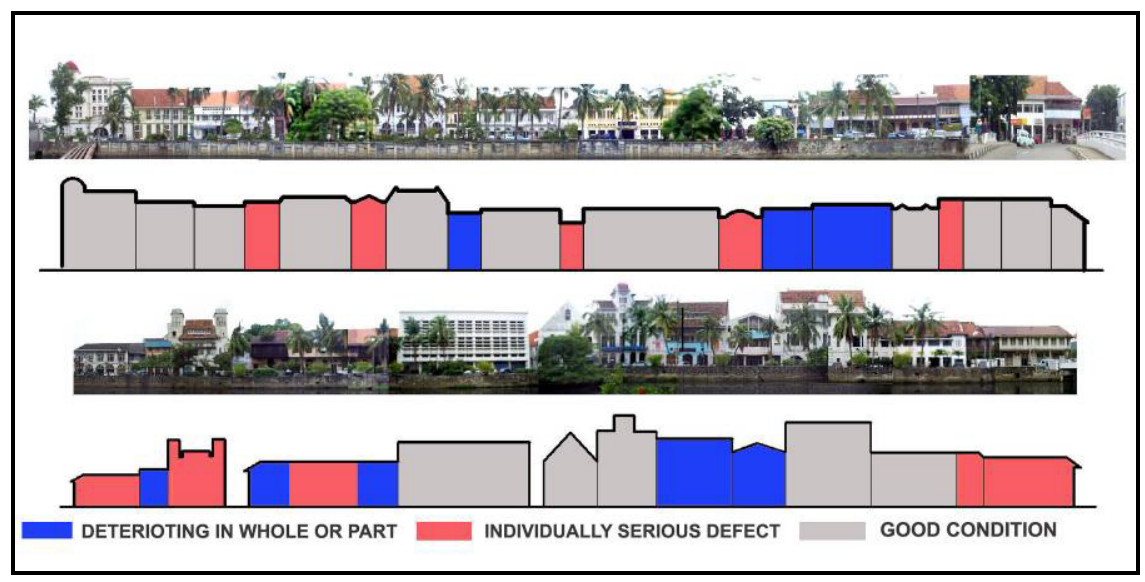

Figure 5: Old buildings condition in Kali Besar, the old town area of Jakarta.

Beyond Jakarta, the second largest cities are also undergoing the process of urban transition. They all have the same problem of transformation in their core areas. Urban centers that were formed as starting points of the city structure formed by the Dutch now remain as the center city areas. Here the bulk of the buildings are constantly changing, either expanding or reconstructing. Examination of the building transformation in the inner city area of Medan reveals that a series of minor changes are occurring alongside the major scale changes [13]. Fortunately, in reference to Kostof, urban transformation still can be categorized as incremental changes, where the cities are transformed through a step-by-step process of hundreds of small-scale alterations and adjustments [14]. These kinds of transformations do not affect the city layout in that the backbone of the inner city formed during the colonial period still can be recognized very clearly.

While the city structure inherited by the Dutch still remains, a tour in the historical area of colonial cities emphasizes how widespread and how comprehensive are the changes on existing old buildings. The emergence of the 
new pattern of urbanscape is apparent. The existing districts, though still have clearly recognizable layouts; tend to merge together into disorderly agglomerations within larger cities. The juxtaposition of numerous disparate elements characterize the urban landscape. The mixture of new and old elements within a confined area set by the Dutch constitutes one of the peculiar characteristics of colonial towns and cities.

\section{Sustainability of spatial context}

Although colonial periods are often regarded as a time of bitterness that instigated wars of independence, there is an acceptance of the colonial legacy as part of an official heritage definition. Examination of the resident's intentions about the significant architectural heritage in Medan also reveals a strong awareness and high regard toward colonial buildings [15]. There is no doubt, with the growing political maturity, that the country is able to reassess the significance of the Western elements and take steps to protect the best examples. However, attention should not be given merely to old buildings. More important is the effort to highlight the image of the cities as former colonial towns. Colonial towns left impressions, which remain and shape succeeding built-forms of varying styles produced in the subsequent periods. Therefore, colonial cities can be identified as a local language of Indonesian urban form. For that reason, sustainability of the spatial context of colonial cities could be accomplished by maintaining an intrinsic sense of a colonial urban space.

For fast growing cities like Jakarta, Medan, Semarang, Surabaya and other big cities, protecting the existence of the Dutch layer of urban form is becoming a difficult task. It often happens that urban redevelopment is often based on the desire to obtain the greatest possible economic profits, which tends to demolish old buildings rather than to protect them. Therefore, an attempt to set the guideline for defining the final form of preservation models for colonial cities is needed. It could be argued that there is no need for such an image as urban form that is so complicated and dynamic. It would be futile to envisage a final form. However, we need to confine the spatial and visual control tools, which address developing the general framework as the instrument for negotiation in the development process of historic centers. Successful urban spaces are designed; they do not just happen. We can only reclaim the visual completeness of the past again if we are willing to accept urban design guidelines that establish the way in which urban space can grow. Yet the guideline is a form of network that links many complexities and contradictions of the city into a coherent form.

The framework of an urban design guideline is to set the historical core as an epitome of the former colonial city. To do this, the best landmarks built by the Dutch can be considered as the key townscape, which interacts with the less valuable old features (Figure 6). In this way, these linkages will produce the morphological entity that would form the constituent part within the total townscape. Indeed, this should proceed with a restoration program upon isolated sites and neglected old buildings, which then follows on by taking concrete actions to preserve particular old buildings. 

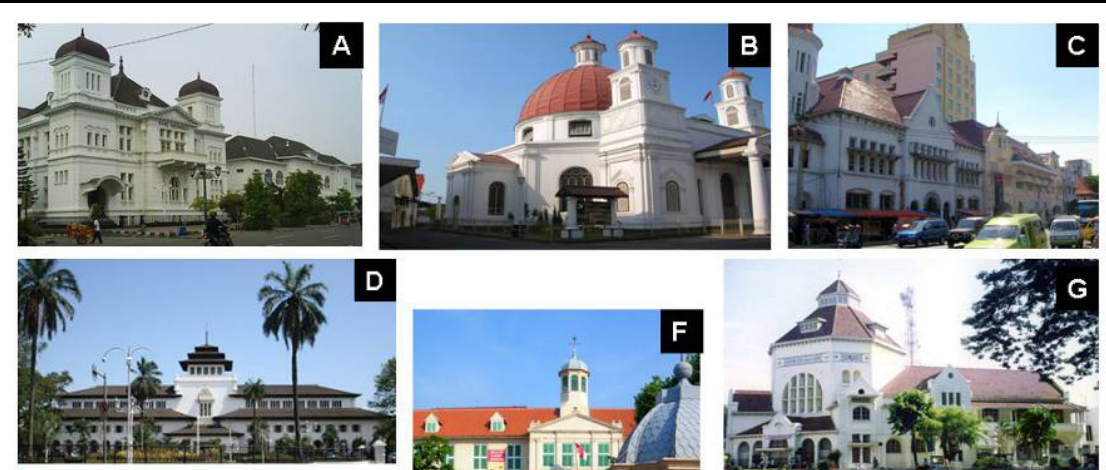

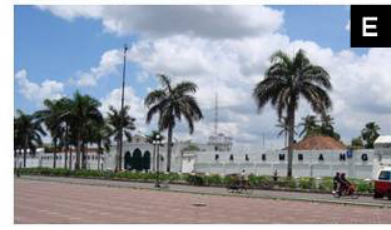

A. BANK (YOGYAKARTA)

B. CHURCH (SEMLRANG)

C. OFFICES (SURABAYA)

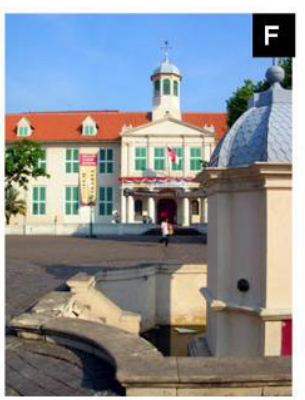

D. CITY HALL (BANDUNG)

E. FORT (PALEMBANG)

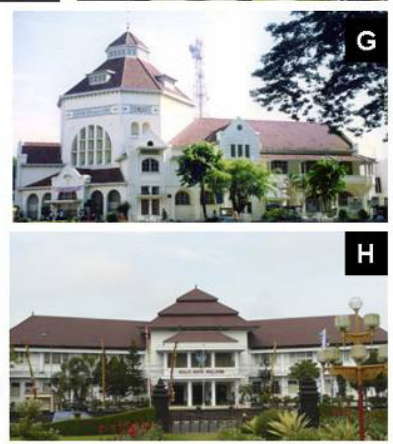

F. MUSEUM (JAKARTA)

G. POST OFFICE (MEDAN)

H. CITY HALL (MALANG)

Figure 6: $\quad$ Example of existing remaining old buildings in big cities.

\section{Sustainability of living functions}

The guideline should not only modify the arrangement of the physical elements of the city, but also could display a historic urban area that serves the role as a central function without destroying its original character. It is a common solution to preserve the historic centre and to allow the new development to grow in another location, especially for the cities in Indonesia where abundant land areas are available. But then the historic area would become an empty stage set, a spectacle for tourists that might be a pleasant place to visit, but will be unreal and common. Then the best way is to regulate the balance between protection of a selective part of the historic centre from changes (of heavy traffic, massive technological changes, etc.) and justification of the rest of the areas for further development, using appropriate means to enable the historic area for maintaining its role as the city centre.

Ideally, if a centre is to stay alive, it must change to meet its new functions, and this means a shift, but not a total break from daily activities and still holding on to its role as the place to live for many citizens from various classes. As shown in the second largest cities in Indonesia, although the tendencies of building transformations in the core area are considerably high, urban kampungs and shop houses are still resistant to functional change [16]. They are still considered as the place to live for residents from various incomes. Accordingly, since inhabitants are key factors in maintaining the area as a liveable place, coexistence between the place to live and work should be preserved. An integrated 
urban planning program that considers certain efforts to encourage urban habitation of various groups of income will lead to liveability and sustainability within the historical area.

\section{References}

[1] Nas, Peter, J.M, (eds). The Indonesian Cities, Foris Publication: Dord'reht Cummanminson, Holland, pp. 33, 1986

[2] Murphey, Y., Rhoads, Urbanization in Asia, Ekistics, 21, pp. 8-17, 1966

[3] Rutz, Werner, Cities and Towns in Indonesia, Gebruder Borntraeger: Berlin. Stuttgart, pp. 51-58, 1987

[4] Heiden, C.N., Town Planning in the Dutch Indies, Planning Perspectives, Volume 5, Issue 1 January 1990, pp. 63-84, 1990

[5] Wertheim, W.F. (eds). Selected Studies on Indonesian by Dutch Scholars, The Royal Tropical Institute: Amsterdam, pp.viii, 1958

[6] Mulyono, Slamet, Menuju Puncak Kemegahan Sejarah Kerajaan Majapahit, Balai Pustaka, Jakarta, pp.44-46, 1965

[7] Ikaputra, et al., A Study on the Transformation of Symbolic Square in Javanese Historical Cities. Journal of Japanese Urban Planning, 29, pp.337, 1994, Jakarta, 1968

[8] Gill, Ronald, the Morphology of Indonesian Cities an Introduction to the Morphology of Colonial Settlements and Towns in Java, Proc. of the Seminar Change and Heritage in Indonesian Cities, Jakarta, 1988

[9] Ellisa, Evawani, et al., A Historical Study of the Urban Area Composition and Character of Medan Town During the End of Colonial Age, Journal of Japanese Urban Planning, 30, pp. 452-453, 1995

[10] Milone, Pauline Dublin, Queen City of the East: the Metamorphosis of Colonial Capital, Graduate Division of the University of California, Berkeley, pp.159, 1966

[11] http://www.tageo.com/index-e-id-cities-ID.htm

[12] Silver, Christopher, Planning the Megacity, Jakarta in the Twentieth Century, Routledge, New York, pp. 82-125, 2008

[13] Ellisa, Evawani, et al., A Study on the Building Transformation in the Historical Core City Area, Journal of Japan Architecture, Planning and Environmental Engineering, 501, Architecture Institute of Japan, pp. 163173, 1997

[14] Kostof, Spiro, the City Assembled: the Elements of Urban Form through History, Thames and Hudson: London, 1992

[15] Ellisa, Evawani, et al., A Study on the Resident's Intention about the Significant Architectural Heritage in the Former Colonial City, Journal of Japanese Urban Planning, 32, pp. 7-12, 1997

[16] Ellisa, Evawani, et al., A Study on the Resident's Intention to Live in Shop Houses, Case Study on the Urban Center Area of Medan, Journal of Japanese Urban Planning, 33, pp. 523-528, 1998 